study programmes on organization of assistance in the event of major disasters.

The task of establishing and standardizing the terminology relating to major disasters has been entrusted to the Spanish delegation, which will present this proposal at the next meeting, to be held on 1 and 2 December 1986 in Istanbul, at the invitation of the Turkish Government. The fifth informal meeting of the Ministers might be held in Greece, at the invitation of the Greek Government, which will be setting up a European pilot centre for forecasting earthquakes.

The parliamentary Assembly of the Council of Europe is following with especial interest the work done in the fields of forecasting and prevention of disasters, and also on cooperation between the states of southern Europe-not only to forecast disasters, but also to protect and safeguard the cultural heritage.

\title{
The Centre For Science and Environment in India
}

The Centre for Science \& Environment (CSE) was set up in 1980 in New Delhi as a non-profit, non-governmental, quasi-academic, research organization. Its aim is to promote public awareness of the role of science and technology in Indian national development. More specifically, it explores issues concerning environment and development in India.

It was founded by Anil Agarwal, an Indian Institute of Technology graduate who had worked as a journalist on 'The Hindustan Times' and the 'Indian Express' in Delhi and as the Assistant Editor of the Earthscan feature agency in London. Most of the research and writing staff of the CSE are science graduates or journalists.

One of the first activities for the CSE was to run a feature service for newspapers. In 1982, it published the State of India's Environment-A Citizens' Report, which for the first time examined not only different facets of the deterioration of the country's environment in painstaking detail but also established the interconnection between those different facets. The report, published as a hardback volume of nearly 200 pages, won acclaim in India and abroad, and has become the biggest single source of information on the country's environment.

* Being reviewed for our Journal by Dr M.S. Swaminathan, FRS, FNA, Director-general of the International Rice Research Institute and President of IUCN. - Ed.

Nore: We would like to commend this initiative most warmly and express the ardent hope that it will be emulated in more and more countries having similarly enlightened heads of Government who are disposed to seek independent expert advice on pressing or foreseeable environmental problems. $-\mathrm{Ed}$.
Three years later, the CSE followed up with a second report*, which covered new ground and dealt with new problems, and which included a long section on the causes and consequences of the Bhopal gas-leak tragedy. It has already sold some 5,000 copies and is exactly twice as voluminous as the first book. Like the first Report, it has been widely extracted and reviewed in the Indian and foreign press. Prime Minister Rajiv Gandhi has recently asked the CSE, on the basis of the second Report, to brief the entire Indian Cabinet of Ministers and all the Members of Parliament on the threat to India's environment. Yet another publication of CSE is Temples Or Tombs? by the undersigned, which deals with three industrial projects that triggered off environmental controversies in the country.

One of the remarkable features of CSE's activities is that it has until recently been able to support itself almost entirely by the sales of its books. It is now working on others, two of which are to be entitled 'India's Cooking Energy Crisis' and the 'State of India's Urban Environment'. The CSE also does networking on environmental issues with NGOs in India and abroad.

\section{Energy from a Fishpond}

Falling oil prices make little difference to poor farmers in the Third World whose resources cannot be stretched to buy power at any price and who, all too frequently, are remote from principal sources of supply. Hence the interest of a UNESCO enterprise in Paraguay, to develop a device for on-farm supplies of energy from biogas.

The biogas is produced by the breakdown of aquatic plants from a fishpond. Microorganisms work on the aquatic plants (which can be supplemented with animal manure) to decompose them in a biodigester (see caption to Fig. 2) in which organic matter is further decomposed. It is based on a Chinese model, and yields around nine cubic metres of gas a day.

Integrating the installation with a fishpond has several advantages: it helps the farmer to raise his energy capacity with the biogas, and it also increases his foodstocks with fish from the pond, as well as supplying fertilizers and animal fodder from the aquatic plants.

UNESCO's Regional Office for Science and Technology (ROSTLAC) in Montevideo helped to develop the system, which was designed by research workers at the Institute of Basic Sciences in the National University at Asuncion, led by Dr R. Fitzpatrick, a former UNESCO official. The installation has been set up at the Enrique de Osso College for the Promotion of Rural Women in Asuncion.

The students, who come from inland regions of the country, will spread the idea in their own villages. A training course for peasants together with instruction manuals are foreseen. 